\title{
Phytochemical Screening, Antioxidant, Antibacterial, Antifungal Potential and in vivo Acute Toxicity of the Crude Extract of Cordia Rothii and Viola Serpens
}

Hafiz Muhammad Zubair ( $\nabla$ dr.zubair83@gmail.com )

The University of Lahore https://orcid.org/0000-0002-0500-3249

Muhammad Naveed

Nanjing Medical university

Reyaj Mikrani

department of clinical pharmacy, China pharmaceutical university

Najm ul Hassan

The University of Lahore

Abdoh Taleb,

School of Pharmacy, Nanjing medical university

Muhammad Ibrahim

Saffron pharmaceutical, Faisalabad

Irfan Anjum

Faculty of Pharmacy, the university of Lahore

Mirza Muhammad Fran Ashraf Baig

State key laboratory of analytical chemistry for life sciences,school of chemistry and chemical engineering, Nanjing University

Qaiser Jabeen

Department of Pharmacy, the Islamia university of Bahawalpur

Research

Keywords: Natural products, antioxidant, antibacterial, acute toxicity

Posted Date: July 30th, 2020

DOI: https://doi.org/10.21203/rs.3.rs-45018/v1

License: (1) (1) This work is licensed under a Creative Commons Attribution 4.0 International License.

Read Full License 


\section{Abstract}

Background: Plants contain numerous bioactive compounds with valuable pharmacological activities and can be used as a novel therapeutic agent.

Methods: The objective of the current study was to evaluate phytochemical screening, antioxidant, antibacterial, antifungal, and acute toxicity capacity of Cordia rothii (CR) and Viola serpens (VS) plant extract.

Results: The phytochemical screening revealed the presence of saponins, tannins, anthraquinones, and flavonoids contents. Antioxidant activity of both extracts was measured by total phenolic, total flavonoid content, DPPH, and reducing power capacity. $\mathrm{IC}_{50}$ value of $C R$ and $V S$ extract was calculated as $0.039 \pm$ $0.05,0.05 \pm 0.07 \mathrm{mg} / \mathrm{ml}$ respectively. Both extract have antibacterial activity against $S$. aureus and $S$. epidermidis, whereas $V S$ is inactive against $E$. coli. Antifungal activity was not found in both $C R$ and $V S$ extract. The $\mathrm{LD}_{50}$ of the test substance was also estimated to be over $10 \mathrm{~g} / \mathrm{kg}$ body weight.

Conclusions: The conclusion indicates that folkloric uses of both plants in traditional settings, the extracts possess antibacterial activity with remarkable antioxidant ability.

\section{Background}

Plants source is an ancient remedy and tonic to cure against diseases and health complaints. The use of medicinal plants has become popular and increases as herbal medicines, because of affordable, culturally acceptable, and effective with minor side effects as compared to synthetic drugs. In many centuries people have been demanding to assuage and treat diseases through plant extracts and natural formulations (1). The attention to the plant holding antimicrobial properties has been invigorated due to serious problems, especially pathogen resistance-associated due to the prolonged use of antibiotics. In the current scenario, microorganisms tend to develop resistance and turn out undesirable side effects, which may offer extensive potential for new therapeutic agents (2-4).

Cordia rothii $(C R)$ Roem and Schult, the specie of the Boraginaceae family, locally called gondhi. It is traditionally used as an anti-diarrheal, antiseptic, anti-inflammatory, anti-diabetic (5), to reduce burning sensation of the urinary tract, wound healer, diuretic, hepato-protective, in abscess and chronic fever (6). Plants of genus Cordia are highly reputed for their diverse pharmacology and phytochemistry. However, $C R$ is relatively less explored specie. A previous study demonstrated that $C R$ roots showed strong antibacterial and antioxidant activity (7) whereas phytochemically and pharmacologically, its leaves arenot investigated.

Viola serpens (VS) wall, member of Violaceae family, traditionally used to cure jaundice, lung and blood disorders $(8,9)$, febrifuge, potent aphrodisiac and diaphoretic effects, headache, cough, cold, dermatitis, kidney diseases, liver, lungs and urinary infections (10). The various species of $V S$ are distributed in Afghanistan, Bhutan, Malaysia, Thailand, Indonesia, Sri Lanka, China, and Pakistan as well (11). The 
study demonstrated that VS leaves showed strong antioxidant activity (12) but whole plant was not investigated so far.

To explore for such a new therapeutic compound has become the goal of microbiologists to reduce further spreading infections. A literature survey reported that strong antioxidants neutralize reactive oxygen species (ROS) and works as a remedy against various diseases neurodegenerative, cardiovascular, bacterial and fungal infections (13). However, there is no evidence was reported about the effects of $C R$ leaves and whole plant of $V S$ against bacterial and fungal pathogens. So the current study aims to evaluate potential of in vitro phytochemical screening, antioxidant, antibacterial, antifungal, and in vivo acute toxicity analysis of aqueous methanolic extracts of $C R$ and $V S$.

\section{Materials And Methods}

\section{Plant collection}

The $C R$ plant was collected from the dessert of Bahawalpur, Pakistan whereas VS plant was purchased from the local market of DIKhan-Pakistan. These plants were authenticated by a taxonomist from the department of botany, the Islamia University of Bahawalpur, Bahawalpur, Pakistan. The plant samples were kept in the herbarium of the pharmacology section for the record.

\section{Aqueous metabolic extracts}

Dried plant materials were cleaned from dust, coarsely grounded by using a mechanical grinder (poly mix PX-MFC-90D). The coarse powder of each plant was soaked in $70 \%$ aqueous methanol separately and then filtered. The dark greenish and yellowish-brown color, semisolid crude extract from $C R / V S$, the extract yield were achieved $20.4 \%$ and $12.3 \%$ respectively through evaporation under reduced pressure using a rotary evaporator at $40^{\circ} \mathrm{C}$. The concentrates were preserved in a separate container, appropriately labeled, and stored in the refrigerator at $4^{\circ} \mathrm{C}$ for further study.

\section{Phytochemical screening}

Both extracts were subjected to examination for the identification of phytochemical compounds according to the procedures (14).Qualitative screening of the alkaloids, glycosides, ferric chloride (phenols and tannins), saponins, triterpenoids, and flavonoids were performed by using Mayer's and Dragendroff reagents, Keller-Killiani foam, Salkowski, and lead acetate tests (15).

\section{Quantification of total phenolic content (TPC)}

TPC of the extract was performed through the spectrophotometer method (16). $300 \mu$ from extract solution was added into $2.25 \mathrm{ml}$ of Folin-Ciocalteu reagent that was already ten times diluted with deionized water. After five minutes, $6 \%(\mathrm{w} / \mathrm{v})$ sodium carbonate $\left(\mathrm{Na}_{2} \mathrm{Co}_{3}\right)$ solution was added, mixed it directly, and allowed to stand for $90 \mathrm{~min}$ at room temperature. The absorbance of the solutions was taken at $725 \mathrm{~nm}$ on the UV-VIS spectrophotometer (IRMECO U2020, Germany). Gallic acid was used as a 
standard. The result of TPC was expressed in $\mathrm{mg}$ of gallic acid equivalent/ $100 \mathrm{~g}$ of the extract (mg $\mathrm{GAE} / 100 \mathrm{~g} \mathrm{DW}$ ). The experiment was repeated in the triplicate manner, and the mean was calculated as average.

\section{Quantification of total flavonoid content (TFC)}

TFC in the extracts was performed through the spectrophotometer according to the method with slight modification $(1,17) .1 \mathrm{mg} / \mathrm{ml}$ of the extract solution was added into $150 \mu \mathrm{l}$ of $5 \%$ sodium nitrite solution $\left\{\left(\mathrm{NaNO}_{2}\right)\right.$, Merck, Germany $\}$. After six min, the mixture of $150 \mu$ of $10 \%$ aluminum chloride solution $\left(\mathrm{AlCl}_{3}\right.$. $\left.6 \mathrm{H}_{2} \mathrm{O}\right)$ and $4 \%$ sodium hydroxide $(\mathrm{NaOH})$ were added. A new volume of the mixture was maintained up to $5 \mathrm{ml}$ by methanol. After $15 \mathrm{~min}$, absorbance was measured at $510 \mathrm{~nm}$; flavonoid content was expressed as $\mathrm{mg} \mathrm{RE} / 100 \mathrm{~g}$ of rutin. The experiment was repeated in the triplicate manner, and mean was considered as average.

\section{Determination of free radical scavenging activity}

The free radical scavenging activity of the extract was evaluated through the DPPH method with minor modifications $(18,19)$. The extract solution was added to $0.16 \mathrm{mM} \mathrm{DPPH}$ solution in methanol, incubated for $60 \mathrm{~min}$ at room temperature in the dark, and the absorbance was measured at $517 \mathrm{~nm}$ on a spectrophotometer (IRMECO U2020, Germany). Ascorbic acid was used as standard; the experiment was performed in a triplicate manner, and the mean was considered as average. The scavenging activity was calculated by following formula.

Scavenging effect (\%) $\otimes 1-\left(\mathrm{Abs}_{0}-\mathrm{Abs}_{1}\right) \times 100 / \mathrm{Abs}$

$\mathrm{Abs}_{0} \rrbracket$ Absorbance of extract plus DPPH solution

$\mathrm{Abs}_{1} \otimes$ Absorbance of the extract/standard

Abs $₫$ Absorbance of DPPH solution

\section{Reducing power capacity}

The ferric reducing capacity of the extracts was examined through the potassium ferricyanide-ferric chloride method (20). The extract solution was mixed with the mixture of $200 \mathrm{mM}$ phosphate buffer having $\mathrm{pH} 6.6$ and $1 \%$ potassium ferricyanide $\left\{\mathrm{K}_{3} \mathrm{Fe}(\mathrm{CN})_{6}\right.$ (Merck, Germany) $\}$, and the mixture was incubated at $50{ }^{\circ} \mathrm{C}$ for $20 \mathrm{~min}$. The ferricyanide to ferrocyanide reaction was stopped by adding $10 \%$ $(\mathrm{w} / \mathrm{v})$ trichloroacetic acid solution $\left\{\mathrm{C} \mathrm{Cl}_{3} . \mathrm{COOH}\right.$, (Merck, Germany)\}. The solution was centrifuged at 3000 rpm for $10 \mathrm{~min}$, and the upper layer was collected, diluted with distilled water, and then added a freshly prepared ferric chloride $\left(\mathrm{FeCl}_{3}\right)$ solution. The absorbance was measured at $700 \mathrm{~nm}$ on a spectrophotometer. Gallic acid was used as standard, and the experiment was repeated in triplicate manner. 


\section{Preparation of inoculums}

A loopful of cells from stock cultures of $S$. aurous (ATCC 6538), S. epidermidis (ATCC 12228), E-coli (ATCC 8739), C. albicans (ATCC 10231), and A. niger (ATCC 16404) were mixed with sterile nutrient broth (Merck, Germany) separately and incubated at $37^{\circ} \mathrm{C}$ for $10-18$ hours for acquire colonies and compared the turbidity of $0.5 \mathrm{McF}$ arland standard $\left(1-2 \times 10^{8} \mathrm{CFU} / \mathrm{ml}\right)(21,22)$.

\section{In vitro antibacterial and antifungal assay}

The antimicrobial activity of the crude extract was performed according to the disc diffusion method (23). $250 \mathrm{mg}$ of crude extract was dissolved in $2.5 \mathrm{ml}$ of sterile distilled water; $50 \mu \mathrm{l}$ of this solution was transferred onto a disc (6 $\mathrm{mm}$ in diameter). The extract containing dried discs were placed in petri dish holding Mueller-Hinton agar $\{(\mathrm{MHA})$, Merck, Germany) $\}$ and sabouraud dextrose agar media (Oxide, USA). The media was pre-inoculated with bacterial and fungal suspension $\left(10^{8} \mathrm{CFU} / \mathrm{ml}\right)$ then incubated at $36 \pm$ $1^{\circ} \mathrm{C}$. Gentamicin $(40 \mu \mathrm{g})$, terbinafine $(20 \mu \mathrm{g})$, and water containing discs were used as standard or control. The experiments were repeated in the triplicate manner and were calculated as the average zone of inhibition.

\section{Minimum inhibitory and bactericidal concentrations (MIC and MBC) assay}

The MIC of the extract was determined by the modified agar well diffusion method at a concentration range of $0.078-10 \mathrm{mg} / \mathrm{ml}$ suggested by method (24). $100 \mu \mathrm{l}$ from each dilution of crude extract was introduced into $6 \mathrm{~mm}$ wells MHA media containing petri plate, which was pre-inoculated with a specific strain. The least concentration required to inhibit the growth of microorganisms was noted. MBC of the extracts was performed through a nutrient agar plate method with slight modification (24). 2-3 loops of bacterial cells were taken from MIC wells, mixed in a small amount of sterile normal saline, and agitated well. Sterile nutrient agar media containing plate was inoculated uniformly through disposable sterile swab sticks and then incubated for $24 \mathrm{~h}$. The lowest concentration required to kill microorganisms and produced no visual growth was noted as MBC.

\section{In vivo acute toxicity activity}

Acute toxicity of the extract was evaluated on healthy C57BL/6 mice according to the method (25). Male and female mice were kept under controlled environmental conditions (humidity, temperature) with $12 \mathrm{~h}$ of light/dark cycle, allowed free access to water and diet, mice were randomly divided into four groups; one control and three treated/test groups (each group containing six mice). A single oral dose of normal saline $(10 \mathrm{ml} / \mathrm{kg})$ was given to the control group, whereas treated/test groups received $1,3,10 \mathrm{~g} / \mathrm{kg}$ body weight dose of the extract. After this, mice were observed for abnormality and mortality for subsequent $0.5,1,3,6,12$, and $24 \mathrm{~h}$. At the end of the assessment, blood was taken from all the survived mice for measurement of AST, ALT level.

\section{Statistical analysis}


The current project data was analyzed using Microsoft excels and reported as the mean standard deviation $( \pm S D$ ) of triplicate experiments. Moreover, nonlinear regression using Prism 6 (Graph Pad Software, Inc., USA) program was used to calculate $\mathrm{IC}_{50}$ from the dose-response curve.

\section{Results}

\section{Phytochemical composition of plant extracts}

The phytochemical screening result of $C R$ and $V S$ extracts revealed the presence of saponins, tannins, anthraquinones, and flavonoids contents (Table 1). Previous studies reported that these secondary metabolites have many biological effects, including antibacterial and antifungal activities $(26,27)$. Furthermore, effects of these biological activities mostly based on presence of high antioxidant activity.

Table 1

Qualitative phytochemical screening of $C R$ and VSextract

\begin{tabular}{|llll|}
\hline $\begin{array}{l}\text { Phytochemical } \\
\text { constituents }\end{array}$ & Test & CR extract & VS extract \\
\hline Alkaloids & Mayer's and Dragendroff test & - & - \\
\hline Saponins & Foam test & - & + \\
\hline Flavonoids & Shinoda test & + & + \\
\hline Glycosides & Keller-Killiani test & - & - \\
\hline Phenols and tannins & Ferric chloride test & + & + \\
\hline Coumarin & Fluorescence test & - & - \\
\hline Steroids and terpenoids & Salkowski's test & - & - \\
\hline$(+) \otimes$ Present, $(-) \otimes$ absent & & & \\
\hline
\end{tabular}

\section{Total phenolic content (TPC)}

Phytochemical screening is the major tool for qualitative and quantitative analysis of herbal compounds (28). Phenolic contents in plant extract have a highly positive relationship with anti-oxidant activity (29). These are ubiquitous secondary metabolites; they have a major role in plant defense through neutralizing ROS $(30,31)$. In the current study, both extracts are full of phenolic content; but $C R$ extract has higher phenolic content as compared to VS (Table 2). 
Table 2

Quantitative phytochemical constituents of Cordia rothii(CR) and Viola serpens

\begin{tabular}{|c|c|c|c|c|}
\hline Plant species & $\begin{array}{l}\text { TFC } \\
\text { (mg.RE/100 g) }\end{array}$ & $\begin{array}{l}\text { TPC } \\
(\mathrm{mg} . \mathrm{GAE} / 100 \mathrm{~g})\end{array}$ & $\begin{array}{l}\text { Reducing Power } \\
\text { (mg.GAE/100 g) }\end{array}$ & $\begin{array}{l}\text { DPPH } \\
\left(\mathrm{IC}_{50}\right)\end{array}$ \\
\hline $\begin{array}{l}\text { Aqueous methanolic extract of } \\
C R\end{array}$ & $183.60 \pm 4.06$ & $75.16 \pm 1.73$ & $79.16 \pm 1.03$ & $\begin{array}{l}0.039 \pm \\
0.05\end{array}$ \\
\hline Aqueous methanolic VS & $101.24 \pm 2.09$ & $55.42 \pm 2.1$ & $51.21 \pm 1.11$ & $\begin{array}{l}0.050 \pm \\
0.07\end{array}$ \\
\hline$(n \otimes 3)$ & & & & \\
\hline
\end{tabular}

\section{Total flavonoid content (TFC)}

The phenolic and flavonoids are secondary plant metabolites containing the aromatic compounds with hydroxyl groups. They are utilized in plants pigment production and also attract the insects for pollination. The flavonoids are important phytochemical that used in many biological functions such as anti-inflammatory, allergic, and cancer but these cannot be synthesized naturally in animals (1). The high level of phenolic contents enclosed high flavonoid content (32). In the present study, both extracts are jam-packed of flavonoids; $183.6 \pm 11.06$ and $101.238 \pm 2.06 \mathrm{mg} \mathrm{RE} / 100 \mathrm{~g}$ in $C R$ and VS extracts, respectively (Table 2 ).

\section{DPPH free radical scavenging activity}

The DPPH-free radical scavenging activity is based on the principle that any content of plant extracts donate hydrogen or electron to neutralize the DPPH-H molecule (18). Previous facts showed that the use of natural antioxidants can protect against the analogous health effect precipitated by oxidative damage to lipids, proteins, and DNA (33). Both extracts have significant DPPH scavenging activity, but the $\mathrm{IC}_{50}$ of the $C R$ was lower than VS extract (Fig. 1).

\section{Reducing power capacity}

This assay is a method of assessing the capacity of an antioxidant to donate an electron, results in the reduction of the ferric cyanide complex (Fe3+) to the ferrous cyanide form (Fe2+) (34). The reducing power results of both extracts have significantly levels of reducing power capacity. The $C R$ extract shoed 1.5 fold higher $(79.16 \pm 1.03)$ reducing power capacity than $V S$ extract $(51.21 \pm 1.11)$ as mentioned in Fig. 1.

\section{Antibacterial activity}

Quantitative assessment of antimicrobial activity of the extract considered to evaluate the presence of inhibition zones, zone diameter, and MIC values. The result of MIC and MBC were presented in Table 3-4. 
The results of CR showed significant antibacterial activity against $S$. aurous (ATCC 6538), S. epidermidis (ATCC 12228), E. coli (ATCC 8739) bacteria. In comparison, CR extract showed a significant antibacterial activity at 1,3 , and $10 \mathrm{mg} / \mathrm{ml}$ concentration whereas $V S$ showed only at $10 \mathrm{mg} / \mathrm{ml}$ (Fig. 2-3). The aqueous methanolic plant extracts of $C R$ have higher antibacterial activity as compared to $V S$. The $C R$ and VS extracts didn't show any significant antifungal activity against $C$. albicans (ATCC 10231), and $A$. niger (ATCC 16404) at all three concentrations; 1,5 and $10 \mathrm{mg} / \mathrm{ml}$ (Fig. 4-5).

Table 3

Minimum inhibitory concentration (MIC) values (mg/ml) for Cordial rothii (CR), Viola serpens (VS) and standard drug

\begin{tabular}{|lccl|}
\hline Bacteria & $\begin{array}{l}\text { Methanol extract } \\
\text { of } C R\end{array}$ & $\begin{array}{l}\text { Methanol extract } \\
\text { of } V \boldsymbol{S}\end{array}$ & $\begin{array}{l}\text { Positive control } \\
\text { (Gentamicin) }\end{array}$ \\
\hline $\begin{array}{l}\text { Staphylococcus aureus ATCC } \\
6538\end{array}$ & $0.156 \pm 0.01$ & $>0.312 \pm 0.00$ & $<0.078 \pm 0.00$ \\
\hline $\begin{array}{l}\text { Staphylococcus epidermis } \\
\text { ATCC 12228 }\end{array}$ & $0.156 \pm 0.00$ & $>0.312 \pm 0.01$ & $<0.078 \pm 0.00$ \\
\hline Escherichia coli ATCC 8739 & $0.312 \pm 0.00$ & $>0.625 \pm 0.01$ & $<0.078 \pm 0.00$ \\
\hline ATCC $\otimes$ American type collection center, values are mean \pm SD $(\mathrm{n} \otimes 2)$. & \\
\hline
\end{tabular}

Table 4

Minimum bactericidal concentration (MBC) values $(\mathrm{mg} / \mathrm{ml})$ for Cordial rothii $(C R)$, Viola serpens $(\mathrm{VS})$ and standard drug

\begin{tabular}{|llll|}
\hline Bacteria & $\begin{array}{l}\text { Methanol extract } \\
\text { of CR }\end{array}$ & $\begin{array}{l}\text { Methanol extract } \\
\text { of VS }\end{array}$ & $\begin{array}{l}\text { Positive control } \\
\text { (Gentamicin) }\end{array}$ \\
\hline $\begin{array}{l}\text { Staphylococcus aureus ATCC } \\
6538\end{array}$ & $0.312 \pm 0.00$ & $>0.625 \pm 0.01$ & $<0.078 \pm 0.00$ \\
\hline $\begin{array}{l}\text { Staphylococcus epidermis } \\
\text { ATCC 12228 }\end{array}$ & $0.312 \pm 0.01$ & $>0.625 \pm 0.01$ & $<0.078 \pm 0.00$ \\
\hline Escherichia coli ATCC 8739 & $0.625 \pm 0.01$ & $>0.625 \pm 0.00$ & $<0.078 \pm 0.00$ \\
\hline ATCC $\otimes$ American type collection center, values are mean \pm SD $(\mathrm{n} \otimes 2)$. & \\
\hline
\end{tabular}


Table 5

Bodyweight changes in post-treated mice

\begin{tabular}{|c|c|c|c|c|c|}
\hline \multirow[t]{2}{*}{ Name of extract } & \multirow[t]{2}{*}{ Parameter } & \multicolumn{4}{|c|}{ Dose of extract ( $\mathrm{g} / \mathrm{kg}$ body weight) } \\
\hline & & \multicolumn{4}{|c|}{0 (Control) 1310} \\
\hline \multirow[t]{2}{*}{$C R$} & Initial body weight (g) & $18.8 \pm 1.21$ & $19.2 \pm 0.29$ & $18.9 \pm 0.8$ & $19.0 \pm 1.0$ \\
\hline & Final body weight $(\mathrm{g})$ & $19.0 \pm 1.98$ & $19.0 \pm 0.33$ & $19.1 \pm 0.51$ & $18.8 \pm 1.1$ \\
\hline \multirow[t]{2}{*}{$V S$} & Initial body weight (g) & $20.1 \pm 4.21$ & $18.7 \pm 0.29$ & $18.6 \pm 0.56$ & $19.3 \pm 1.2$ \\
\hline & Final body weight (g) & $19.9 \pm 3.98$ & $18.9 \pm 0.25$ & $18.4 \pm 0.49$ & $19.4 \pm 0.9$ \\
\hline
\end{tabular}

\section{In vivo acute toxicity activity}

Single dose administration of $1,3,10 \mathrm{~g} / \mathrm{kg}$ body weight of $C R$ and $V S$ extract was used to evaluate in vivo acute toxicity study. After dose administration, signs of toxicity like; weight variation, skin and fur, eyes, respiration, and behavior pattern, and mortality in all animals were observed periodically after $30 \mathrm{~min}, 1$, $2,3,6,12$ and then $24 \mathrm{~h}$. All the mice $(\mathrm{n}=42)$ were survived (zero mortality rate) and no significant difference was observed in body weight (Table.5). Therefore both extracts may consider as safe upto the dose of $10 \mathrm{~g} / \mathrm{kg}$ body weight.

\section{Discussion}

Presently, a rapid increase in the number of studies on medicinal plants due to presence of phenolic, flavonoid, and phenolic acid compounds which have been observed owing to antioxidant and antibacterial activities (35). These phytochemical contents diverge depending on the plant's species, tissue, developmental stage, and environmental factors, such as temperature, water stress, and light conditions $(3,36)$. These aspects are usually accountable for color, taste, impediment of fat oxidation and prevention of enzymes, and vitamin degradation in food (3). Another important factor is oxidative stress, has been implicated in several diseases. While phenolic acids and flavonoids (abundantly found in plant) act as natural antioxidants; neutralize oxidative stress/ROS and enhance biological functions (37). However the present study was undertaken with the aim to show phytochemical screening, antioxidant, antibacterial, antifungal, and acute toxicity assessment of $C R$ and $V S$ plant extracts.

The phytochemical screening result of $C R$ extracts exposed the presence of flavonoids, phenols and tannins whereas VS extract contained saponins, flavonoids and phenols and tannins (Table 1).Previous data related to phytochemical screening exposed that ethanolic extract of VS showed the presence of amino acids, reducing sugars and flavonoids(12). These phytochemical constituents in medicinal plants contain antioxidant activity, play role in plant defense; act as toxic material to the pathogens $(38,39)$. 
Phenols are the secondary metabolites containing an aromatic ring that allow the donation of hydrogen atoms/electrons from their hydroxyl groups, work as free radical terminators, and are known to be poisonous to microbes (40). In current study, antioxidant assessment was evaluated by four different methods. TPC results showed $C R$ extract $(75.16 \pm 1.73)$ has higher potency than $V S(55.42 \pm 2.1)$. Additionally, flavonoids are also well-known plant secondary metabolites being endowed with a wide range of biological effects such as antioxidant, antiinflammatory, hepatoprotective, anticancer, antiviral, and antibacterial. Mostly flavonoids occur as aglycones and glycosylated and methylated derivatives, while glycosylated flavonoids are abundant in the human daily diet (41-43). Moreover, flavonoid makes a complex with extracellular or soluble proteins of bacterial cell walls (lipophilic) and may also disrupt bacterial membrane $(35,44)$. Our results showed that both extracts contained much quantity of flavonoid contents but $C R$ extract (183.60 \pm 4.06$)$, has higher capacity as compared to VS (101.24 \pm

2.09).Furthermore, another method is the DPPH-assay, based on the principle that any substance capable of donating hydrogen/an electron, so antioxidant potency is verified through DPPH method. In this process, color changed from purple to yellow owing to the formation of neutral DPPH-H molecule upon the uptake of a hydrogen atom from antioxidant species $(1,45)$. Concentration of the extracts capable of reducing the initial DPPH absorbance by $50 \%$, demonstrated as $I C_{50}$. Present study, $I C_{50}$ value of $C R$ and VS extract was calculated as $0.039 \pm 0.05,0.05 \pm 0.07 \mathrm{mg} / \mathrm{ml}$ respectively (Table. 2). The result of reducing power capacity is further verified that $C R(79.16 \pm 1.03)$ has stronger antioxidant potential than $V S(51.21 \pm 1.11)$. The strong reducing power capacity is linked with presence of powerful antioxidant potency in medicinal plants (46). Our results showed that presence of strong antioxidant activity in both extracts due to the existence of phenolic and flavonoid contents which have the ability to scavenge, and reduced (Table 2).

Antioxidant and antimicrobial correlation has been evaluated in many earlier studies $(7,47)$. In current study, $C R$ extract results showed significant antibacterial activity was found against Gram positive $S$. aureus (21.930 \pm 1.43$)$, S. epidermidis (18.340 \pm 1.98$)$, and Gram negative E.coli (12.730 \pm 1.13 ) at a dose of $10 \mathrm{mg} / \mathrm{ml}$. These facts elucidated that $C R$ extract showed a higher zone of inhibition against grampositive as compared to gram-negative bacteria (Fig. 2). Whereas antifungal activity was not found in $C R$ extract against $C$. albicans and $A$. niger at 1,5 , and $10 \mathrm{mg} / \mathrm{ml}$ (Fig. 4). It is reported that $C R$ root showed strong antibacterial but without antifungal activity (7). Conversely, VS extract showed weak antibacterial activity against $S$. aureus $(9.76 \pm 1.25)$, $S$. epidermidis $(8.96 \pm 0.62)$, and $E$. coli $(7.0 \pm 1.02)$ at same doses. The VS extract has a significant zone of inhibition against gram-positive only, whereas no activity was evaluated against $E$. coli as well as $C$. albicans and $A$. niger (Figs. $3 \& 5$ ). Numerous citations are also available for the connection between antioxidant potential and phenolic content. Presence of antibacterial effects in both extracts may be due to the occurrence of a high quantity of phenolic and flavonoid content $(44,48)$. These constituents considered to work as a powerful antioxidant, antiinflammatory, and antimicrobial compound. Therefore, antibacterial activity of $C R$ and $V S$ extracts could be due to antioxidant capacity to scavenge free radicals/chelate dangerous compounds and prevent oxidative stress (39). 
Recently, advance in living standards and medical technology has increased researches to develop pharmaceutical products from natural products. Health safety from functional plant is of concern to consumers. Misused of functional plant may have toxic effects. Therefore, it is critical to confirm their safety through acute toxicity tests (49). Acute toxicity test results showed there were no signs of toxicity and body weight changes observed in extract treated and the control group mice. The signs of toxicity i.e. changes in body weight skin, fur, eyes, respiration, behavior pattern, and mortality. The results showed that there was no death observed in all experimental groups after extract administration (data not shown). The $\mathrm{LD}_{50}$ of the test substance was also estimated to be over $10 \mathrm{~g} / \mathrm{kg}$ body weight. Furthermore, hepatotoxicity causes elevation in the levels of hepatocellular enzymes such as AST and ALT (50). In the current study, no elevation of AST and ALT levels was observed in extract treated mice. These results suggest that both extracts ( $C R$ and $V S$ ) has no hepatotoxic effect. Furthermore, potential deadly adverse effect was not seen in extract treated mice. Based on results of no toxicological changes, $C R$ and $V S$ plant extract might be safe and used as an alternative or adjuvant treatment. One of the major drawbacks of medicinal plant extract is that it generally has low bioavailability and efficacy due to its solubility and absorption problems but these issues can be overcame by new preparation technology such as nanoparticle which helps increasing solubility and absorption, and further minimizing toxicity of medicinal plant extract.

\section{Conclusions}

Initially our data confirmed the presence of strong antioxidant capacity due to presence of phenolic and flavonoids in both plant extract. Secondly, microbiological screening exhibits potent antibacterial activity but without antifungal activity that may provide good efficacy against various infections and diseases. Thirdly, in vivo acute toxicity results confirmed safety of both plant extract. Fourth, comparison data showed that $C R$ extract contained higher amount of phenolic, flavonoid, antioxidant and antibacterial activity with zero mortality rates. In conclusion, these results demonstrating broad spectra of antibacterial activity in $C R$ extract might be more helpful to discover a new compound that may be used as novel biochemical for infectious diseases and other biological functions in the future.

\section{Abbreviations}

(VS): Viola serpens, (CR): Cordiarothii; S. aureus: Staphylococcus aureus; S. epidermidis; Staphylococcus epidermidis, E.coli: Escherichia coli; ROS: reactive oxygen species; ATCC: American type culture collection; MIC: Minimum inhibitory concentration; DPPH: 2,2-diphenyl-1-picrylhydrazyl; TPC: Total phenolic content; TFC: Total flavonoid content; MBC: Minimum bactericidal concentration; MHA: Mueller-hinton agar; CFU: Colony forming unit; $C$. albicans: candida albicans, A.niger: Aspergillus niger, $\left\{\mathrm{K}_{3} \mathrm{Fe}(\mathrm{CN})_{6}\right\}$ : Potassium ferricyanide; $\mathrm{NaOH}$ : sodium hydroxide; $\mathrm{AlCl}_{3}$. $6 \mathrm{H}_{2} \mathrm{O}$ : Auminum chloride solution.

\section{Declarations}

\section{Ethics approval and consent to participate}


The animal study was in accordance with the Guide for the Care and Use of Laboratory Animals (National Institutes of Health). The study protocol was approved by the local animal ethics committee of Faculty of Pharmacy, the Islamia University of Bahawalpur, Pakistan.

\section{Consent to publish}

Not applicable

\section{Availability of data and materials}

Most of the data in the current study are included in this article.

\section{Competing interests}

The authors declare that they have no competing interests.

\section{Funding}

Not applicable

\section{Authors' contributions}

$\mathrm{MI}, \mathrm{NH}$ and IA designed the study; $\mathrm{HMZ}$ performed in vitro antioxidant, antimicrobial activates and in vivo acute toxicity; MMFAB and TA analyzed the data; HMZ, MN and RM wrote this manuscript; QJ revised this manuscript. We all read and then approved the final manuscript.

\section{Acknowledgements}

The authors would like to thank Mr. Naveed Aslam, Faculty of Pharmacy, the Islamia University of Bahawalpur, Pakistan in language correction and also thank to Saffron Pharmaceuticals Pvt Ltd for providing the ATCC bacterial and fungal strains.

\section{References}

1. Larayetan R, Ololade ZS, Ogunmola OO, Ladokun A. Phytochemical Constituents, Antioxidant, Cytotoxicity, Antimicrobial, Antitrypanosomal, and Antimalarial Potentials of the Crude Extracts of Callistemon citrinus. Evidence-Based Complementary and Alternative Medicine. 2019;2019.

2. Barua CC, Sen S, Das AS, Talukdar A, Hazarika NJ, Barua AG, et al. A comparative study of the in vitro antioxidant property of different extracts of Acorus calamus Linn. J Nat Prod Plant Resour. 2014;4(1):8-18.

3. Chaves N, Santiago A, Alías JC. Quantification of the Antioxidant Activity of Plant Extracts: Analysis of Sensitivity and Hierarchization Based on the Method Used. Antioxidants. 2020;9(1):76.

4. Shinwari ZK, Gilani SS. Sustainable harvest of medicinal plants at Bulashbar Nullah, Astore (northern Pakistan). Journal of Ethnopharmacology. 2003;84(2-3):289-98. 
5. Chauhan MG, Chavan SS. Pharmacognosy and biological activity of Cordia rothii Roem. \& Schult. bark. 2009.

6. Ghori V, Gatecha H, Desai T, Pandya D. Pharmacognostic Study of Leaves of Cordia rothii Linn. Pharmacognosy Journal. 2011;3(22):35-8.

7. Khan K, Firdous S, Ahmad A, Fayyaz N, Nadir M, Rasheed M, et al. GC-MS profile of antimicrobial and antioxidant fractions from Cordia rothii roots. Pharmaceutical biology. 2016;54(11):2597-605.

8. Bhattacharjee S, De L. Medicinal Herbs and Flowers'. Pp-434. Published by Aavishkar Publishers \& Distributors, Jaipur, Rajasthan (ISBN ...; 2005.

9. Ur-Rehman E. Indigenous knowledge on medicinal plants, village Barali Kass and its allied areas, District Kotli Azad Jammu \& Kashmir, Pakistan. Ethnobotanical Leaflets. 2006;2006(1):27.

10. Sher Z, Khan Z, Hussain F. Ethnobotanical studies of some plants of Chagharzai valley, district Buner, Pakistan. Pak J Bot. 2011;43(3):1445-52.

11. Toiu A, Pârvu A, Oniga I, Tămaş M. Evaluation of anti-inflammatory activity of alcoholic extract from Viola tricolor. Revista medico-chirurgicala a Societatii de Medici si Naturalisti din lasi. 2007;111(2):525-9.

12. Kumar A, Chauhan P, Bhardwaj V, Kumar R, Tyagi A. In vitro antioxidant and phytochemical investigations of ethanolic extracts of Viola serpens and Morus nigra. J Chem Pharm Res. 2011;3(4):166-71.

13. Valko M, Leibfritz D, Moncol J, Cronin MT, Mazur M, Telser J. Free radicals and antioxidants in normal physiological functions and human disease. The international journal of biochemistry \& cell biology. 2007;39(1):44-84.

14. Basri DF, Fan S. The potential of aqueous and acetone extracts of galls of Quercus infectoria as antibacterial agents. Indian journal of Pharmacology. 2005;37(1):26.

15. Gilani AH, Jabeen Q, Khan A-u, Shah AJ. Gut modulatory, blood pressure lowering, diuretic and sedative activities of cardamom. Journal of ethnopharmacology. 2008;115(3):463-72.

16. Kim D-O, Jeong SW, Lee CY. Antioxidant capacity of phenolic phytochemicals from various cultivars of plums. Food chemistry. 2003;81(3):321-6.

17. Zengin G, Aktumsek A, Guler GO, Cakmak YS, Yildiztugay E. Antioxidant Properties of Methanolic Extract and Fatty Acid Composition of Centaurea urvillei DC. subsp. hayekiana Wagenitz. Records of Natural Products. 2011;5(2).

18. Duan X-J, Zhang W-W, Li X-M, Wang B-G. Evaluation of antioxidant property of extract and fractions obtained from a red alga, Polysiphonia urceolata. Food chemistry. 2006;95(1):37-43.

19. Sun L, Zhang J, Lu X, Zhang L, Zhang Y. Evaluation to the antioxidant activity of total flavonoids extract from persimmon (Diospyros kaki L.) leaves. Food and chemical toxicology. 2011;49(10):2689-96.

20. Singhal M, Paul A, Singh HP. Synthesis and reducing power assay of methyl semicarbazone derivatives. Journal of Saudi Chemical Society. 2014;18(2):121-7. 
21. Djipa CD, Delmée M, Quetin-Leclercq J. Antimicrobial activity of bark extracts of Syzygium jambos (L.) Alston (Myrtaceae). Journal of Ethnopharmacology. 2000;71(1-2):307-13.

22. Cavanagh HM, Hipwell M, Wilkinson JM. Antibacterial activity of berry fruits used for culinary purposes. Journal of medicinal food. 2003;6(1):57-61.

23. Okeke MI, Iroegbu CU, Eze E, Okoli A, Esimone C. Evaluation of extracts of the root of Landolphia owerrience for antibacterial activity. Journal of ethnopharmacology. 2001;78(2-3):119-27.

24. Rahman N, Ahmad M, Riaz M, Mehjabeen JN, Ahmad R. Phytochemical, antimicrobial, insecticidal and brine shrimp lethality bioassay of the crude methanolic extract of Ajuga parviflora Benth. Pak J Pharm Sci. 2013;26(4):751-6.

25. Jabeen Q, Bashir S, Lyoussi B, Gilani AH. Coriander fruit exhibits gut modulatory, blood pressure lowering and diuretic activities. Journal of ethnopharmacology. 2009;122(1):123-30.

26. Doughari JH, Human I, Benadé A, Ndakidemi P. Phytochemicals as chemotherapeutic agents and antioxidants: Possible solution to the control of antibiotic resistant verocytotoxin producing bacteria. 2009.

27. Kamel MS, OHTANI K, KUROKAWA T, ASSAF MH, EL-SHANAWANY MA, ALI AA, et al. Studies on Balanites aegyptiaca fruits, an antidiabetic Egyptian folk medicine. Chemical and pharmaceutical bulletin. 1991;39(5):1229-33.

28. Silva SL, Lucas Tenório CJ, de Lima LB, Procópio TF, de Moura MC, Napoleão TH, et al. Phytochemical analysis and evaluation of the antimicrobial and antioxidant activities of extracts and fractions of Hymenaea eriogyne Benth. Natural product research. 2019:1-5.

29. Velioglu Y, Mazza G, Gao L, Oomah B. Antioxidant activity and total phenolics in selected fruits, vegetables, and grain products. Journal of agricultural and food chemistry. 1998;46(10):4113-7.

30. Sengul M, Yildiz H, Gungor N, Cetin B, Eser Z, Ercisli S. Total phenolic content, antioxidant and antimicrobial activities of some medicinal plants. Pakistan Journal of Pharmaceutical Sciences. 2009;22(1).

31. Ho C-T, Osawa T, Huang M, Rosen T. Food phytochemicals for cancer prevention II. ACS Symphosium. Series 547. American Chemical Society: Washington, DC; 1994.

32. Asong JA, Amoo SO, McGaw LJ, Nkadimeng SM, Aremu AO, Otang-Mbeng W. Antimicrobial activity, antioxidant potential, cytotoxicity and phytochemical profiling of four plants locally used against skin diseases. Plants. 2019;8(9):350.

33. Bickers DR, Athar M. Oxidative stress in the pathogenesis of skin disease. Journal of Investigative Dermatology. 2006;126(12):2565-75.

34. Tuksitha L, Chen Y-LS, Chen Y-L, Wong K-Y, Peng C-C. Antioxidant and antibacterial capacity of stingless bee honey from Borneo (Sarawak). Journal of Asia-Pacific Entomology. 2018;21(2):563-70.

35. Adamczak A, Ożarowski M, Karpiński TM. Antibacterial Activity of Some Flavonoids and Organic Acids Widely Distributed in Plants. Journal of Clinical Medicine. 2020;9(1):109. 
36. Zlatić N, Jakovljević D, Stanković M. Temporal, Plant Part, and Interpopulation Variability of Secondary Metabolites and Antioxidant Activity of Inula helenium L. Plants. 2019;8(6):179.

37. Liang D, Zhou Q, Gong W, Wang Y, Nie Z, He H, et al. Studies on the antioxidant and hepatoprotective activities of polysaccharides from Talinum triangulare. Journal of ethnopharmacology. 2011;136(2):316-21.

38. Achika J, Ayo R, Oyewale A, Habila J. Flavonoids with antibacterial and antioxidant potentials from the stem bark of Uapaca heudelotti. Heliyon. 2020;6(2):e03381.

39. Abou Baker D, Al-Moghazy M, ElSayed A. The in vitro cytotoxicity, antioxidant and antibacterial potential of Satureja hortensis L. essential oil cultivated in Egypt. Bioorganic chemistry. 2020;95:103559.

40. Vanzani P, Rossetto M, De Marco V, Sacchetti LE, Paoletti MG, Rigo A. Wild Mediterranean plants as traditional food: a valuable source of antioxidants. Journal of Food Science. 2011;76(1):C46-C51.

41. Miron A, Aprotosoaie AC, Trifan A, Xiao J. Flavonoids as modulators of metabolic enzymes and drug transporters. Annals of the New York Academy of Sciences. 2017;1398(1):152-67.

42. Kumar S, Pandey AK. Chemistry and biological activities of flavonoids: an overview. The Scientific World Journal. 2013;2013.

43. Morris ME, Zhang S. Flavonoid-drug interactions: effects of flavonoids on ABC transporters. Life sciences. 2006;78(18):2116-30.

44. Perumal Samy R, Gopalakrishnakone P. Therapeutic potential of plants as anti-microbials for drug discovery. Evidence-based complementary and alternative medicine. 2010;7(3):283-94.

45. Guerrini A, Sacchetti G, Rossi D, Paganetto G, Muzzoli M, Andreotti E, et al. Bioactivities of Piper aduncum L. and Piper obliquum Ruiz \& Pavon (Piperaceae) essential oils from eastern Ecuador. Environmental toxicology and pharmacology. 2009;27(1):39-48.

46. Abdul Qadir M, Shahzadi SK, Bashir A, Munir A, Shahzad S. Evaluation of phenolic compounds and antioxidant and antimicrobial activities of some common herbs. International journal of analytical chemistry. 2017;2017.

47. Kibagendi Osoro E, Zhi Hea Y, Ndagijimanab A, Sivoko Imbenzi P. A review on phenolic compounds in Illicium species and their pharmacological effects. Pelagia Res Libr. 2013;4:17-30.

48. Trombetta D, Castelli F, Sarpietro MG, Venuti V, Cristani M, Daniele C, et al. Mechanisms of antibacterial action of three monoterpenes. Antimicrobial agents and chemotherapy. 2005;49(6):2474-8.

49. Ha AW, Kang HJ, Kim SL, Kim MH, Kim WK. Acute and subacute toxicity evaluation of corn silk extract. Preventive nutrition and food science. 2018;23(1):70.

50. Worasuttayangkurn L, Nakareangrit W, Kwangjai J, Sritangos P, Pholphana N, Watcharasit P, et al. Acute oral toxicity evaluation of Andrographis paniculata-standardized first true leaf ethanolic extract. Toxicology reports. 2019;6:426-30. 
Figures

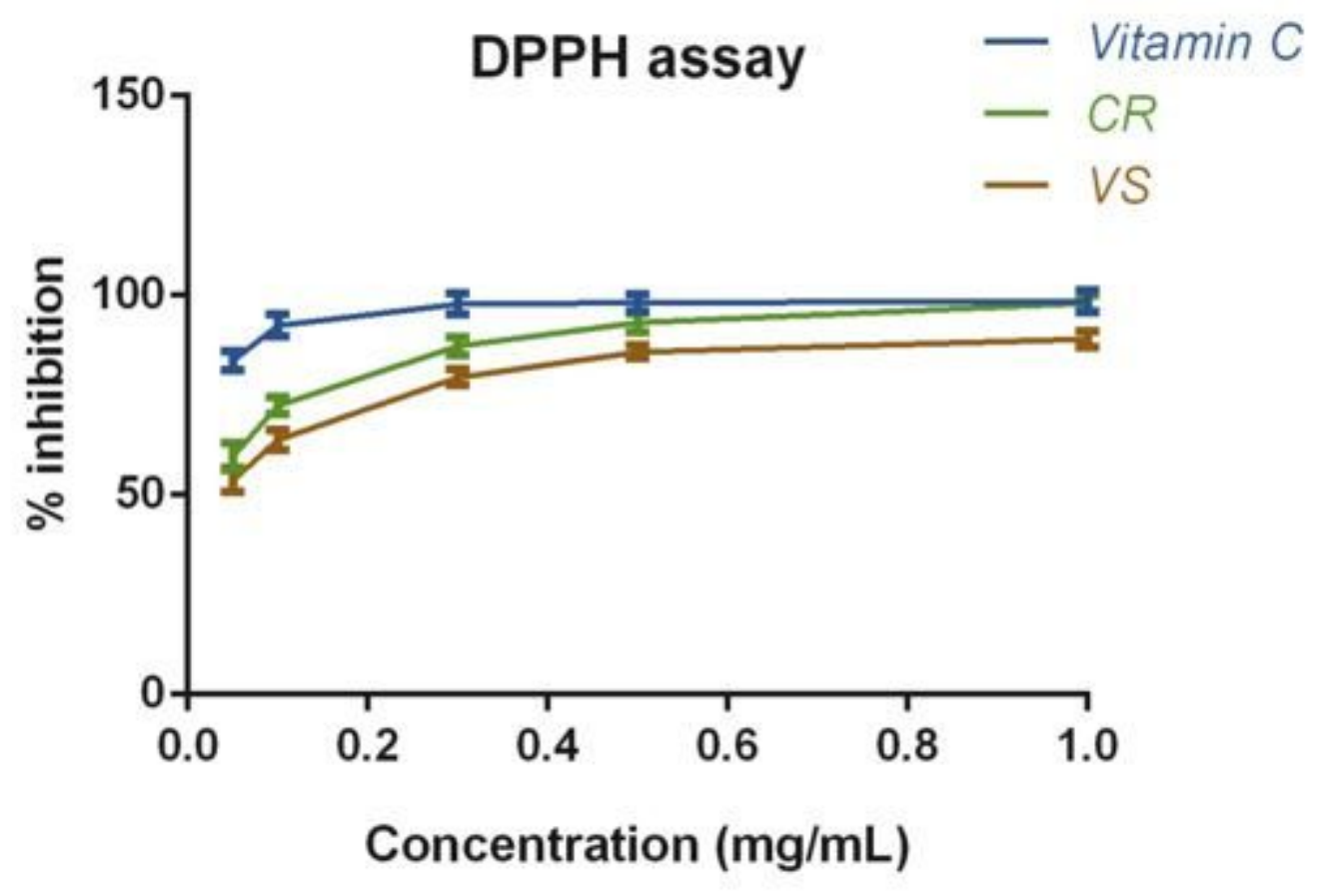

Figure 1

Antiradical effects of C.rothii(CR), V.serpens(VS), and standard drug (vitamin C) on DPPH radicals 


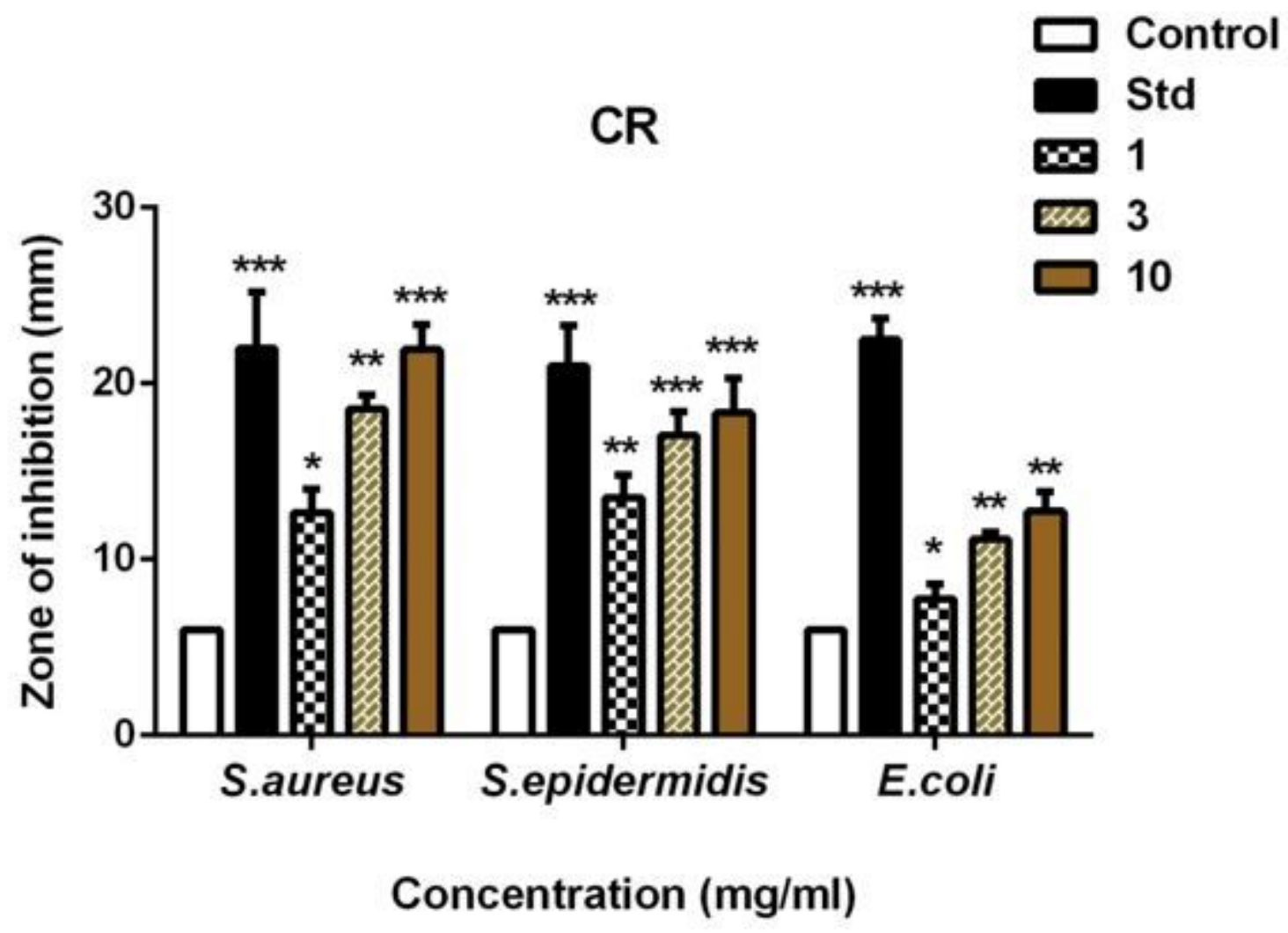

Figure 2

Antibacterial activity (zone of inhibition) of C.rothii (CR), values are presented as mean \pm SD $(n \otimes 3)$. * $p<$ $0.05,{ }^{* *} p<0.01$ and ${ }^{* *} \mathrm{p}<0.001$ represent a statistically significant increase in response to CR treatment 


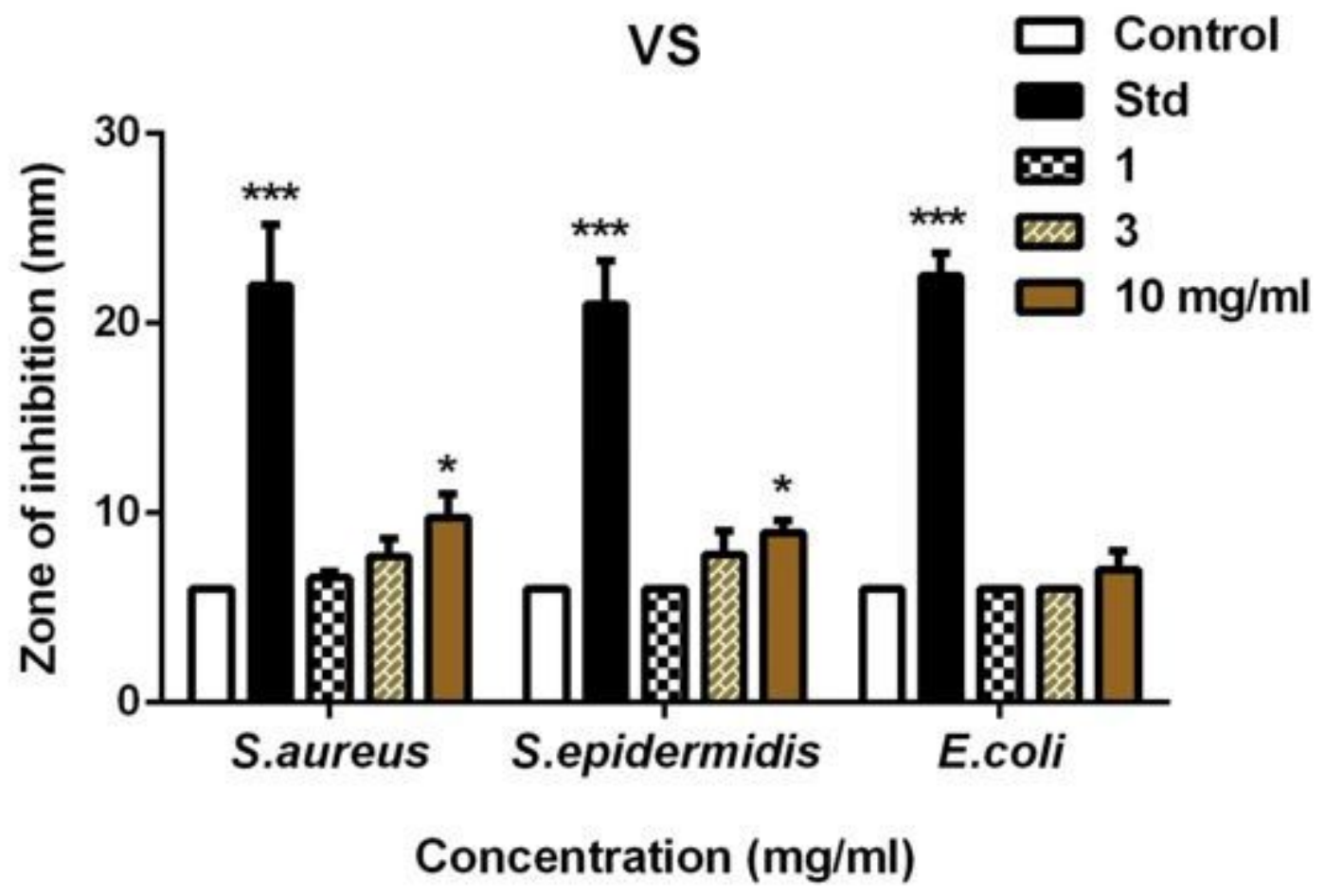

Figure 3

Antibacterial activity (zone of inhibition) of VS extract, values are presented as mean $\pm S D(n \otimes 3) .{ }^{*} p<0.05$, ${ }^{* *} p<0.01$ and ${ }^{* * *} p<0.001$ represent a statistically significant increase in response to VS treatment 


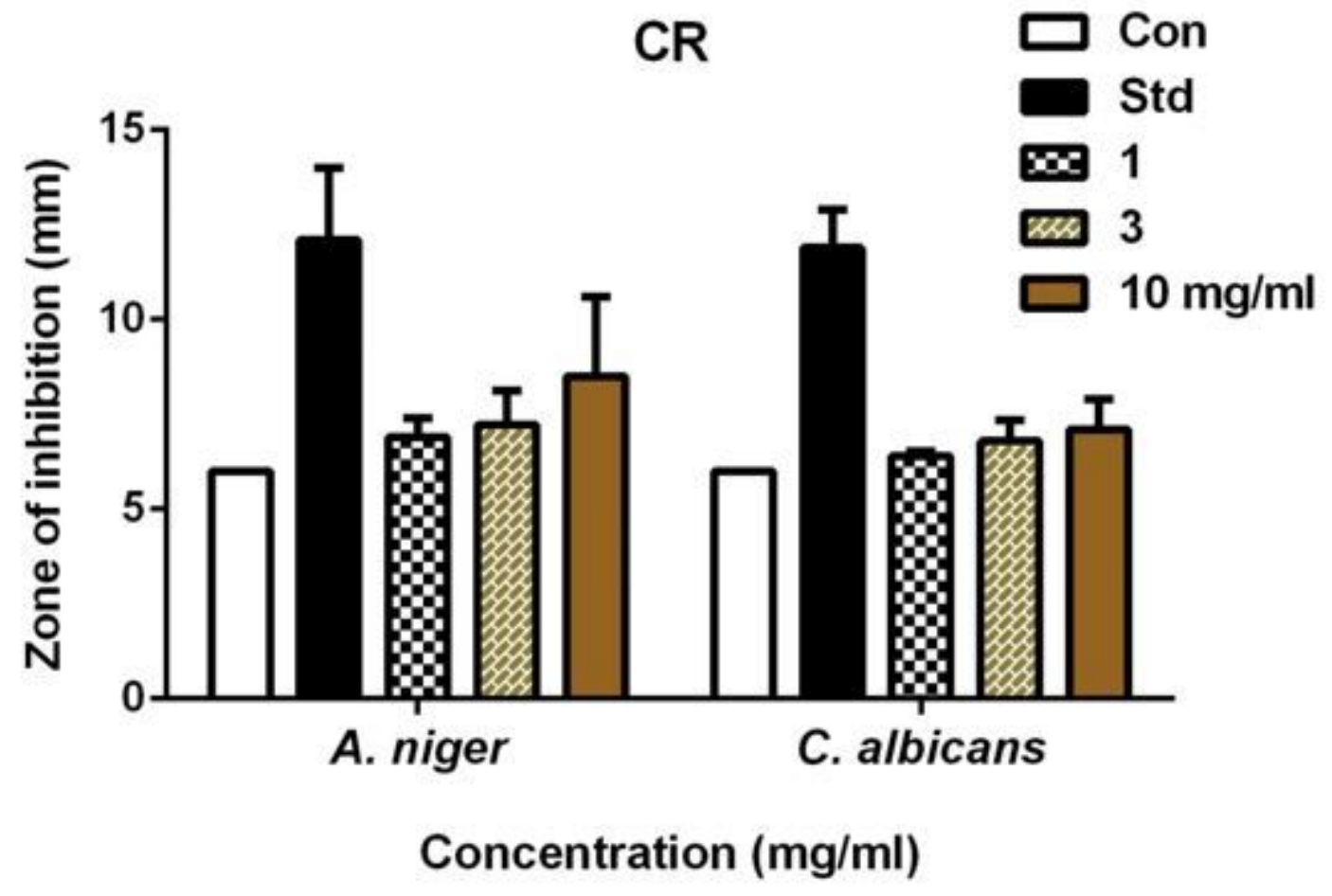

Figure 4

Antifungal activity (zone of inhibition) of CR extract, values are presented as mean $\pm \mathrm{SD}(\mathrm{n} \otimes 3$ ), andp $>0.05$ for all comparisons between CR treated groups and the control group) 


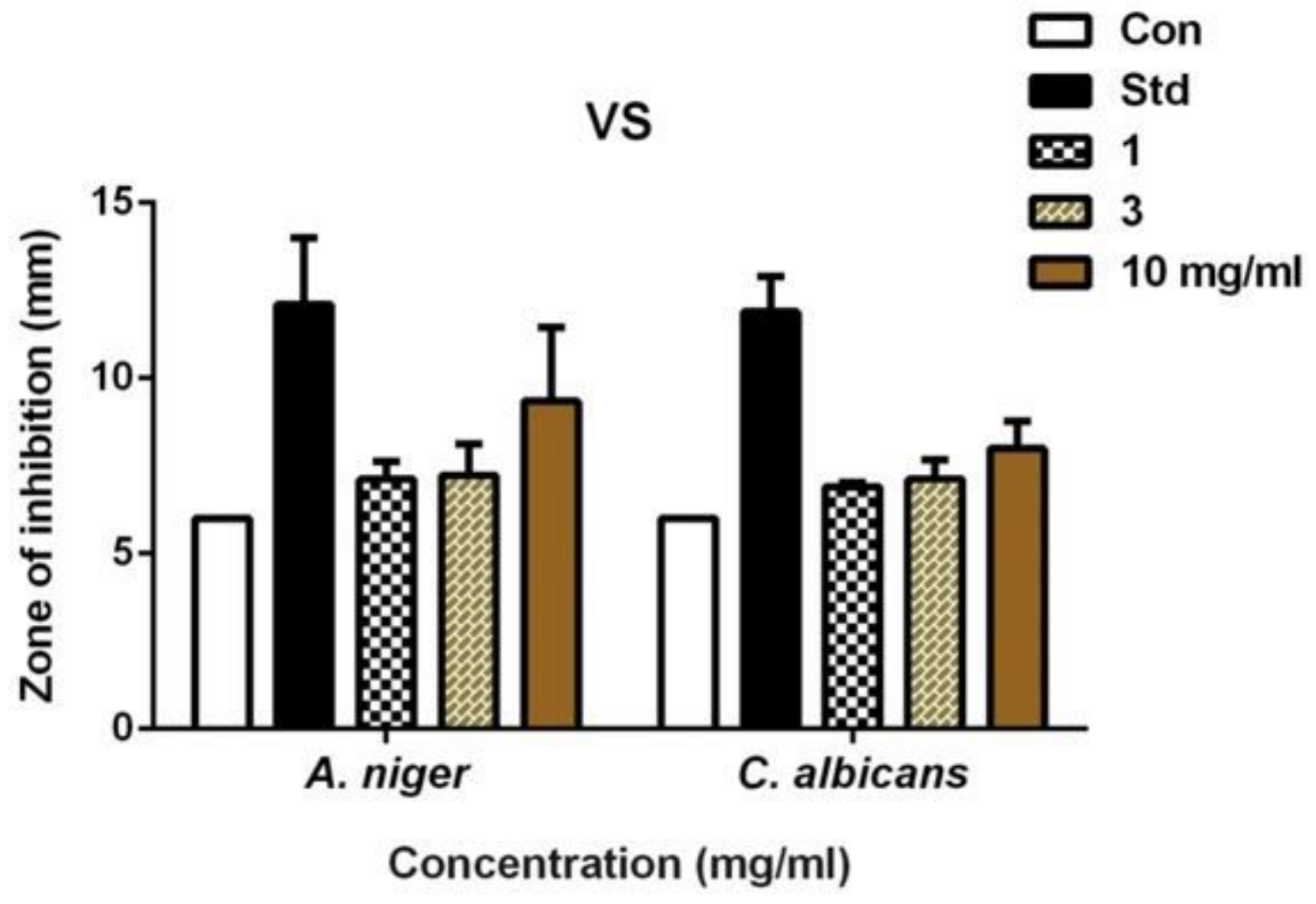

Figure 5

Antifungal activity (zone of inhibition) of VS extract, values are presented as mean $\pm S D(n \otimes 3)$, and $p$ $>0.05$ for all comparisons between VS treated groups and the control group) 